\title{
THE ALCOHOL CONSUMPTION IS AMENDED AFTER BARIATRIC SURGERY? AN INTEGRATIVE REVIEW
}

\author{
O padrão de consumo de álcool é alterado após a cirurgia bariátrica? Uma revisão integrativa
}

Valeria Duarte GREGORIO, Roselma LUCCHESE, IvâniaVERA, Graciele C. SILVA, Andrecia SILVA, Rayrane Clarah Chaveiro MORAES

How to cite this article: Gregorio VD, Lucchese R, Vera I, Silva GC, Silva A, Moraes RCC. The alcohol consumption is amended after bariatric surgery? An integrative review. ABCD Arq Bras Cir Dig. 2018;31(2):e1378. DOI: /10.1590/0102-672020180001e1378

From the Universidade Federal de Goiás (Federal University of Goiás), Goiânia, GO, Brazil

HEADINGS - Substance-related disorders. Bariatric surgery. Alcoholism.

\section{Correspondence:}

Valeria Duarte Gregório

E-mail:valeriadgregorio@gmail.com

Financial source: none

Conflict of interest: none

Received for publication: 18/01/2018 Accepted for publication: 06/03/2018

DESCRITORES - Transtornos relacionados ao uso de sustâncias. Cirurgia bariátrica. Alcoolismo.
ABSTRACT - Background: Bariatric surgery has been an alternative when conservative methods of weight loss fail. Patients undergoing bariatric surgery have an increased risk of up to $6.5 \%$ of problems related to alcohol. Objetive: To review the literature about the changes on alcohol consumption in this public. Method: Database was accessed from June of 2015 to January of 2016 by searching "bariatric surgery" AND "alcoholism", and their Portuguese equivalents. Science Direct, PubMed, Lilacs and Medline, besides manual search, were searched. To be included, the paper should have been published between 2005-2016 and related to bariatric surgery and alcoholism. Theses, dissertations, unpublished papers, case reports and theoretical studies were excluded. In 2005 there was only one review of change in alcohol metabolism in patients undergoing bariatric surgery. There were no publications in 2006. In 2007, only one study was published, and it did not meet the inclusion criteria. In 2010, there was an increase of $13 \%$ in publications and of $20 \%$ in 2012 , reaching $40 \%$ in 2013. Conclusion: The prevalence and incidence of alcohol consumption in relation to the postoperative time was six months to three years with higher incidence in men. Roux-en-Y gastric bypass showed greater association with increased alcohol consumption during the postoperative period. This and other studies showed that the pattern of alcohol consumption is important to be faced as a problem in bariatric surgery follow-up.
RESUMO - Introdução: A cirurgia bariátrica tem-se mostrado alternativa para o insucesso dos métodos conservadores de emagrecimento. Pacientes submetidos à ela têm aumento do risco de 6,5\% de problemas relacionados ao álcool. Objetivo: Realizar revisão integrativa para verificar alteração do consumo de álcool neste público. Método: A base de dados Science Direct, PubMed, Lilacs, Medline e busca manual foram acessadas entre os meses de junho de 2015 a janeiro de 2016 com os descritores "cirurgia bariátrica" e "alcoolismo" e equivalentes em inglês Os critérios de inclusão foram publicações entre junho de 2005 a janeiro de 2016, relacionadas à cirurgia bariátrica e ao consumo de álcool. Foram excluídas teses, dissertações, trabalhos não publicados, relatos de casos e estudos teóricos. Resultado: No ano de 2005 houve somente uma revisão relacionada à alteração do metabolismo do álcool em pacientes submetidos à cirurgia bariátrica. Não houve publicações em 2006. Em 2007, houve uma publicação fora dos critérios deste trabalho. Em 2010 observou-se aumento de publicações em $13 \%$ e $20 \%$ em 2012, atingindo $40 \%$ em 2013. Conclusão: A prevalência e a incidência do consumo de álcool em relação ao tempo de pós-operatório foram de seis meses a três anos com maior incidência em homens. $O$ bypass gástrico em $Y$-de-Roux apresentou maior associação ao aumento do consumo de álcool durante o pós-operatório. Este e outros estudos mostraram que o consumo de álcool se mostrou importante e deve ser enfrentado como potencial problema no seguimento em longo prazo após operação bariátrica.

\section{INTRODUCTION}

(cc) BY This is an open-acces article distributed under the terms of the Creative Commons Attribution License. bout 3.4 million adult deaths annually with cases of obesity, and the prevalence of adult obesity is $11 \%$ globally and $35 \%$ in the United States ${ }^{1}$ In cases in which patients do not show positive responses to conventional weight loss attempts as diet, physical activity and drug therapy, surgery has been taken into account, more precisely the bariatric surgery $(B S)^{24}$.

Aiming to better health conditions, and following strict standards to be performed, the BS has been an alternative and an effective treatment for morbid obesity, in cases that body mass index $\geq 40 \mathrm{~kg} / \mathrm{m}^{2}$ or $\geq 35 \mathrm{~kg} / \mathrm{m}^{24}$ with associated comorbidities (diabetes, sleep apnea, hypertension, dyslipidemia, coronary heart disease and osteoarthritis), failure of well conducted conservative weight loss methods, and absence of alcohol consumption and psychiatric disorders ${ }^{21}$

A situation to be observed before and after the surgery that calls more attention is the alcohol consumption in patients undergoing BS for weight loss ${ }^{11,16}$, which can increase the risk of developing problems related to alcohol abuse in up to $6.5 \%{ }^{26}$.

Among the problems, we can highlight the possibility of transferring compulsive eating to alcohol abuse ${ }^{22,23}$. The prevalence rates indicate an increase of $7.6 \%$ to $9.6 \%$ 
in 12 months after $\mathrm{BS}^{15}$. Studies also show that there is no intention in correcting the problematic ${ }^{2,16}$.

The use of this psychoactive substance prevents regular glycemic control ${ }^{5}$ and causes poisoning and changes with less dosage, compared to the period before the surgery ${ }^{15}$, being considered a challenge in the rehabilitation process ${ }^{15}$.

Considering this problematic for research, the need for an integrative review on alcohol consumption in patients undergoing BS come to light, with the following guiding questions: "Does the pattern of alcohol consumption change in patients undergoing BS?"; "What do the investigations about this subject reveal?"

The objective of this review was to summarize the scientific knowledge produced on the pattern of alcohol consumption in patients undergoing BS between the years 2005 to 2015.

METHOD

This is an integrative review ${ }^{20}$ guided by the question of alcohol abuse among individuals who have undergone $B S$, inquiring about the change or not in the pattern of this substance use in this population. Therefore, Science Direct, PubMed, Latin American and Caribbean Center on Health Sciences Information (LILACS), and Medical Literature Analysis and Retrieval System Online (MEDLINE ${ }^{\circledR}$ ) were accessed.

The search in the databases was conducted between June and August 2015 simultaneously by two researchers. We used the terminology adopted by Health Sciences Descriptors (Decs) and Medical Subject Headings (Mesh), identifying the headings in English and Portuguese version "bariatric surgery" AND "alcoholism". Later, with the selected items, we proceeded with a manual search (hand-search) in their references.

The inclusion criteria for the selection of manuscripts were: results of research that addressed the theme, that is, the relationship between alcohol consumption in patients undergoing BS; field investigations, as original articles and short communication; publications between the years 2005 to 2016 in English, Spanish and Portuguese. Theses, dissertations, unpublished papers, case reports and theoretical studies were excluded, as well as manuscripts that were repeated in databases.

The studies were organized in Excel $2007{ }^{\circledR}$ with records of information guided by the data collection instrument: title, author/year, journal, year of publication, objective, study design, population, level of evidence and main results and conclusions found.

The level of evidence was assigned according to the classification by study design in seven categories ${ }^{24}$ : level 1 , for systematic reviews and meta-analysis of relevant randomized controlled clinical trials or derived from clinical guidelines based on systematic reviews of randomized controlled trials; level 2, for evidence derived from at least one randomized controlled clinical trial and well-designed; level 3, for evidence from well-designed clinical trials without randomization; level 4, for evidence of cohort studies and well-designed case-control; level 5, for evidence of systematic review of descriptive and qualitative studies; level 6, for evidence from a single descriptive or qualitative study; and level 7, for evidence from officials opinion and/or expert committees report ${ }^{19}$.

After this step, the observational analysis was carried out, with assessment of the main types of studies and observation of the relationship between the alcohol consumption and the type of procedure performed.

A database was built with information about changes in the pattern of alcohol consumption and substance abuse in patients undergoing $B S$, in order to facilitate access to major developed research on this topic
RESULTS

In Pubmed were initially found 33 articles and after observational analysis were selected 10 . The themes addressed by the articles were: characterization of the prevalence of alcohol consumption pre and postoperative check with the independent predictors; description of the disorder phenotypes by alcohol abuse by the AUDIT and analysis of the relationship between the degree of weight loss the incidence of AUDIT.

In Science Direct database were initially selected 53 articles and after observational analysis were selected four articles that met the requirements of this review. The issues addressed highlighted the verification of the change in alcohol metabolism after bypass; characterization of alcohol consumption pre and postoperative follow-up for two years of surgery and determination of the associated factors and absorption of alcohol before and after laparoscopic sleeve gastrectomy.

In the Lilacs and Medline databases were found respectively four and 15 articles, but the items were duplicate.

In the manual search two articles were selected. The themes addressed the prospective evaluation of the relationship between the consumption of alcohol and smoking in patients before and after bariatric surgery through the AUDIT and analyze the sensitivity of patients to alcohol consumption after surgery as well as changes in the pattern of consumption during the operative post bariatric surgery.

In total were selected 16 articles describing the title, objectives, level of evidence, instruments used, number of participants and the main aspects and results of each study.

Figure 1 shows the main studies in the past 10 years relating to bariatric surgery to alcohol consumption with emphasis in relation to the objectives, scientific evidence, the instruments used in the studies, number of participants and main characteristics and results found.

In 2005 there were just one review of alcohol absorption and metabolism in bariatric surgical patients. In 2006 there were no publications ${ }^{6}$. In 2007 we found a quantitative study that suggested provide caution regarding alcohol use by gastric bypass patients ${ }^{14}$. In 2009 was found one interventional observational study, but it was not included in this i review because it was a fieldwork ${ }^{9}$. From 2010, the number of publications increased with prevalence of $13 \%^{18,26}$ and this increase continued in 2012 with $20 \%$ of publications ${ }^{10,15,28}$. The year with the highest percentage of publications was 2013 , with a prevalence of $40 \%$ 2,7,16,17,23,29.

From 2013 there was an increase in the number of longitudinal studies (level of evidence IV), in order to respond, with more robust methodologies and greater scientific nature, the changes in the pattern of consumption, the association to the type of bariatric procedure, and attitudes regarding the reduction of alcohol consumption during the postoperative period $^{3,7,8,16,17,23}$

\section{DISCUSSION}

Studies regarding the use of psychoactive substances in patients undergoing $\mathrm{CB}$ showed limitation about the sample size, as $53 \%$ of the studies analyzed showed an average of 90 participants $2,7,11,17,18,26,27,28$ in addition to the restriction of not being considered probabilistic or population-based samples. Five studies were guided by retrospective data collection, which can interfere with the quality of information that, in turn, is dependent on the quality of previous records $8,11,26,28,29$.

Likewise, methodological limitations were observed: $33 \%$ of the studies were cross-sectional type, which makes the causality between effect and exposure/impact ${ }^{5,11,18,26,28}$. However, relevant associated factors for the production of knowledge of this subject could be observed.

At the same time, $43 \%$ of studies presented robust 


\begin{tabular}{|c|c|c|c|c|c|c|}
\hline Reference & Title & Objective & Evidence & Instrument & Participants & Main aspects and results \\
\hline Ashton et al. ${ }^{2}$ & $\begin{array}{l}\text { Pilot evaluation of } \\
\text { a substance abuse } \\
\text { prevention group } \\
\text { intervention for at } \\
\text { risk bariatric surgery } \\
\text { candidates }\end{array}$ & $\begin{array}{c}\text { To assess the substance abuse in a } \\
\text { risk group of patients undergoing } \\
\text { BS }\end{array}$ & $\begin{array}{l}\text { Qualitative } \\
\text { focus group } \\
\text { Level } 6\end{array}$ & AUDIT & 86 & $\begin{array}{l}\text { A significant number of patients reported } \\
\text { an intention to consume alcohol after } \\
\text { surgery }(X 2=16.18 ; p<0.001) \text { and the more } \\
\text { likely reported health reasons as motivation } \\
\text { and therapeutic advice for abstention } \\
\qquad(X 2=102,89 ; p<0.001)\end{array}$ \\
\hline $\begin{array}{l}\text { Buffington } \\
\text { et al. }{ }^{5}\end{array}$ & $\begin{array}{l}\text { Alcohol use and health } \\
\text { risks: survey results }\end{array}$ & $\begin{array}{l}\text { To check sensitivity to alcohol } \\
\text { after surgery, and change and } \\
\text { control in relation to consumption } \\
\text { of alcohol after BS }\end{array}$ & $\begin{array}{l}\text { Quantitative, } \\
\text { transversal and } \\
\text { prospective } \\
\text { Level } 4\end{array}$ & Questionnaire semi-structured & 318 & $\begin{array}{l}\text { Increased sensitivity to the effects of alcohol in } \\
\text { bypass patients. Of the sample, } 28.4 \% \text { patients } \\
\text { had difficulty in controlling the effects of } \\
\text { alcohol in the postoperative period. Surgery } \\
\text { performance time interval was not significant } \\
\text { in sensitivity to alcohol. Higher alcohol } \\
\text { consumption was observed in } 14 \% \text { of patients } \\
\text { compared to the period prior to surgery }\end{array}$ \\
\hline Burgos et $\mathrm{al}^{3}$ & $\begin{array}{l}\text { Prevalence of alcohol } \\
\text { abuse before and } \\
\text { after bariatric surgery } \\
\text { associated with nutritional } \\
\text { and lifestyle factors: } \\
\text { a study involving a } \\
\text { Portuguese population. }\end{array}$ & $\begin{array}{l}\text { Characterize the preoperative } \\
\text { alcohol consumption with follow- } \\
\text { up of two years post-surgery and } \\
\text { to identify associated factors. }\end{array}$ & $\begin{array}{l}\text { Quantitative } \\
\text { longitudinal } \\
\text { Level } 4\end{array}$ & AUDIT & 659 & $\begin{array}{l}\text { Association with alcohol use in males } \\
(p=0.001) / \text { age } \geq 45 \text { years }(p=0.018) \\
\text { and in preoperative with } \mathrm{BMI}<40 \mathrm{~kg} / \mathrm{cm}^{2} \text {. } \\
\text { Prevalence of alcohol use was low during } \\
\text { the postoperative independent of clinical } \\
\text { factors, surgical technique and weight loss } \\
\text { percentage. }\end{array}$ \\
\hline Conason et $\mathrm{al}^{7}$ & $\begin{array}{l}\text { Substance use following } \\
\text { bariatric weight loss } \\
\text { surgery }\end{array}$ & $\begin{array}{l}\text { To check whether patients } \\
\text { undergone WLS have increased } \\
\text { substance use (drug use, alcohol } \\
\text { use and smoking) after surgery to } \\
\text { compensate for the reduction in } \\
\text { food intake }\end{array}$ & $\begin{array}{l}\text { Quantitative, } \\
\text { longitudinal } \\
\text { and prospective } \\
\text { Level } 4\end{array}$ & AUDIT & $\begin{array}{l}155 \text { (100patients } \\
\text { for RYGB and } \\
55 \text { adjustable } \\
\text { gastric banding) }\end{array}$ & $\begin{array}{l}\text { Frequency of alcohol use increased only in } \\
\text { patients who have undergone RYGB }\end{array}$ \\
\hline $\begin{array}{c}\text { Cuellar- } \\
\text { Barboza et al. }\end{array}$ & $\begin{array}{l}\text { Change in consumption } \\
\text { patterns for treatment- } \\
\text { seeking patients with } \\
\text { alcohol use disorder } \\
\text { post- bariatric surgery }\end{array}$ & $\begin{array}{l}\text { To describe the clinical phenotype } \\
\text { disorder of alcohol of patients } \\
\text { with RYGB history, and to compare } \\
\text { it to non- obese, by the AUDIT; } \\
\text { to establish the clinical profile of } \\
\text { patterns of alcohol consumption at } \\
\text { the time of admission and prior to } \\
\text { BS; and to compare those patients } \\
\text { with a group of obese patients } \\
\text { without a history of BS treatment in } \\
\text { the same environment }\end{array}$ & $\begin{array}{l}\text { Quantitative, } \\
\text { longitudinal and } \\
\text { retrospective } \\
\text { Level } 4\end{array}$ & AUDIT Expired alcohol peak & 823 & $\begin{array}{l}\text { Some RYGB patients developed progressive } \\
\text { alcohol consumption. Men looked for } \\
\text { treatment earlier than women }\end{array}$ \\
\hline Davis et $\mathrm{al}^{10}$ & $\begin{array}{l}\text { Gastric bypass surgery } \\
\text { attenuates ethanol } \\
\text { consumption in ethanol- } \\
\text { preferring rats }\end{array}$ & $\begin{array}{l}\text { To check the hypothesis that the } \\
\text { RYGB attenuate ethanol intake } \\
\text { and rewards within the context of } \\
\text { common ethanol consumer }\end{array}$ & $\begin{array}{l}\text { Quantitative, } \\
\text { longitudinal } \\
\text { Level } 4\end{array}$ & $\begin{array}{l}\text { Self-report database of patients } \\
\text { undergoing RYGB }\end{array}$ & 6,165 & $\begin{array}{c}\text { Patients who reported frequent consumption } \\
\text { of ethanol before RYGB reported decrease in } \\
\text { consumption after the surgery }\end{array}$ \\
\hline Ertelt et al..$^{11}$ & $\begin{array}{l}\text { Alcohol abuse and } \\
\text { dependence before and } \\
\text { after bariatric surgery: a } \\
\text { review of the literature } \\
\text { and report of a new } \\
\text { dataset }\end{array}$ & $\begin{array}{l}\text { To assess the prevalence of } \\
\text { alcohol abuse and alcohol } \\
\text { dependence in a sample of BS } \\
\text { patients for bypass before and } \\
\text { after surgery, } 6 \text { to } 10 \text { years of } \\
\text { surgery }\end{array}$ & $\begin{array}{l}\text { Quantitative, } \\
\text { transversal and } \\
\text { retrospective } \\
\text { Level } 4\end{array}$ & Questionnaire semi- structured & 70 & $\begin{array}{l}3 \% \text { of patients undergoing surgery would } \\
\text { develop problems related to alcohol } \\
\text { dependence. On the other hand } 20 \% \text { of } \\
\text { respondents reported intoxication with less } \\
\text { alcohol compared to the period prior to } \\
\text { surgery }\end{array}$ \\
\hline $\begin{array}{l}\text { HagedornJC } \\
\text { et al }{ }^{14}\end{array}$ & $\begin{array}{l}\text { Does gastric bypass } \\
\text { alter alcohol } \\
\text { metabolism? }\end{array}$ & $\begin{array}{l}\text { Verify the alcohol metabolism } \\
\text { changes after bypass surgery }\end{array}$ & $\begin{array}{l}\text { Quantitative, } \\
\text { longitudinal and } \\
\text { retrospective } \\
\text { Level } 4\end{array}$ & $\begin{array}{l}\text { An alcohol breath analysis every } \\
5 \text { minutes symptoms, initial peak } \\
\text { alcohol breath level, time for } \\
\text { alcohol breath levels to normalize. }\end{array}$ & 36 & $\begin{array}{l}\text { Alcohol metabolism was significantly } \\
\text { different between the postgastric bypass and } \\
\text { control groups. The gastric bypass group } \\
\text { did not experience more symptoms than the } \\
\text { control group. This study suggest provide } \\
\text { caution regarding alcohol use by gastric } \\
\text { bypass patients }\end{array}$ \\
\hline Kinget $\mathrm{al}^{15}$ & $\begin{array}{l}\text { Prevalence of alcohol } \\
\text { use disorders before } \\
\text { and after bariatric } \\
\text { surgery }\end{array}$ & $\begin{array}{l}\text { To determine the prevalence of } \\
\text { pre and postoperative AUDIT, as } \\
\text { well as independent predictors of } \\
\text { postoperative AUDIT }\end{array}$ & $\begin{array}{c}\text { Quantitative, } \\
\text { longitudinal } \\
\text { and prospective } \\
\text { Level } 4\end{array}$ & AUDIT & 1,945 & $\begin{array}{l}\text { Increased frequency of alcohol use for } \\
\text { patients undergoing RYGB and adjustable } \\
\text { gastric banding. The prevalence of AUDIT } \\
\text { did not differ between } 1 \text { year pre-surgery to } \\
1 \text { year after surgery }(7.6 \% ; p=0.98) \text {, however } \\
\text { an increased prevalence }(9.6 \% ; p=0.01) \text { was } \\
\text { found after two years of postoperative }\end{array}$ \\
\hline Kudsiet al. ${ }^{16}$ & $\begin{array}{l}\text { Prevalence of } \\
\text { preoperative alcohol } \\
\text { abuse among patients } \\
\text { seeking weight- loss } \\
\text { surgery }\end{array}$ & $\begin{array}{l}\text { Characterize the use of alcohol } \\
\text { in patients contestants bariatric } \\
\text { surgery during the pre-operative. }\end{array}$ & $\begin{array}{c}\text { Quantitative } \\
\text { and longitudinal } \\
\text { Level } 4\end{array}$ & AUDIT & 650 & $\begin{array}{l}\text { High prevalence of high-risk behavior in } \\
\text { patients seeking WLS. Attention to alcohol } \\
\text { preoperatively }\end{array}$ \\
\hline Lentet al. ${ }^{17}$ & $\begin{array}{l}\text { Smoking and alcohol } \\
\text { use in gastric bypass } \\
\text { patients }\end{array}$ & $\begin{array}{l}\text { To evaluate prospective smoking } \\
\text { and alcohol use features before } \\
\text { and after BS; to identify associated } \\
\text { factors with the use of alcohol and } \\
\text { smoking; and to examine the use } \\
\text { of the substance and weight loss }\end{array}$ & $\begin{array}{l}\text { Quantitative } \\
\text { and longitudinal } \\
\text { Level } 4\end{array}$ & AUDIT & 155 & $\begin{array}{l}\text { Patients with higher BMI increased the } \\
\text { likelihood of alcohol consumption in the } \\
\text { postoperative period }\end{array}$ \\
\hline $\begin{array}{l}\text { Maluenda } \\
\text { et al. }{ }^{18}\end{array}$ & $\begin{array}{l}\text { Alcohol absorption } \\
\text { modification after a } \\
\text { laparoscopic sleeve } \\
\text { gastrectomy due to } \\
\text { obesity }\end{array}$ & $\begin{array}{l}\text { To determine the absorption of } \\
\text { alcohol in a group of patients } \\
\text { with morbid obesity before and } \\
\text { after LSG }\end{array}$ & $\begin{array}{l}\text { Quantitative } \\
\text { Level } 4\end{array}$ & $\begin{array}{l}\text { AlcoScan- AL- } \\
\text { 6000(AlcoMateAlcotest): } \\
\text { levelofexhaled air }\end{array}$ & 12 & $\begin{array}{l}\text { Alcohol absorption was altered in morbidly } \\
\text { obese patients after LSG }\end{array}$ \\
\hline Ostlund et al. ${ }^{23}$ & $\begin{array}{l}\text { Increased admission for } \\
\text { alcohol dependence after } \\
\text { gastric bypass surgery } \\
\text { compared with restrictive } \\
\text { bariatric surgery }\end{array}$ & $\begin{array}{l}\text { To evaluate hospitalization for } \\
\text { alcohol abuse before and after BS } \\
\text { and to compare with restrictive } \\
\text { surgery }\end{array}$ & $\begin{array}{c}\text { Quantitative, } \\
\text { longitudinal } \\
\text { and population- } \\
\text { based } \\
\text { Level } 4\end{array}$ & Code registration record & 11,115 & $\begin{array}{c}\text { Patients who undergone bypass had twice } \\
\text { the risk of alcohol abuse and dependence } \\
\text { compared to those who did restrictive } \\
\text { surgery }\end{array}$ \\
\hline Saules et al..$^{26}$ & $\begin{array}{l}\text { Bariatric surgery history } \\
\text { among substance } \\
\text { abuse treatment } \\
\text { patients: prevalence and } \\
\text { associated features }\end{array}$ & $\begin{array}{c}\text { To assess the prevalence of } \\
\text { substance abuse treatment } \\
\text { admissions }\end{array}$ & $\begin{array}{l}\text { Quantitative, } \\
\text { transversal and } \\
\text { retrospective } \\
\text { Level } 4\end{array}$ & Questionnaire & 108 & $\begin{array}{l}\text { Patients undergoing BS and control groups } \\
\text { were predisposed to diagnosis of alcohol } \\
\text { dependence; } 2-6 \% \text { of admissions to treatment } \\
\text { were positive for substance abuse in bariatric } \\
\text { patients; } 6.5 \% \text { of bariatric patients could } \\
\text { develop dependence and alcohol abuse; } \\
\text { higher prevalence of hospital bariatric patients } \\
\text { to women and non-smokers }\end{array}$ \\
\hline Suzuki et al..28 & $\begin{array}{l}\text { Alcohol use disorders } \\
\text { after bariatric surgery }\end{array}$ & $\begin{array}{l}\text { To determine the prevalence } \\
\text { of current AUDIT andother } \\
\text { diagnostics (instruments) in } \\
\text { patients who have undergone BS; } \\
\text { to check if higher weight loss is } \\
\text { associated with a higher incidence } \\
\text { of AUDIT }\end{array}$ & $\begin{array}{l}\text { Quantitative, } \\
\text { retrospective } \\
\text { Level4 }\end{array}$ & AUDIT & 51 & $\begin{array}{l}\text { There were no associations between weight } \\
\text { loss surgeries with development of alcohol } \\
\text { consumption }\end{array}$ \\
\hline Wee et al. ${ }^{30}$ & $\begin{array}{l}\text { High-risk alcohol use } \\
\text { after weight loss surgery }\end{array}$ & $\begin{array}{l}\text { To characterize the high-risk } \\
\text { alcohol consumption before and } \\
\text { after BS (WLS) }\end{array}$ & $\begin{array}{l}\text { Quantitative } \\
\text { and longitudinal } \\
\text { Level } 4\end{array}$ & AUDIT & 541 & $\begin{array}{l}71 \% \text { of patients underwent gastric bypass } \\
\text { and reported improvement of alcohol } \\
\text { consumption when compared to gastric } \\
\text { banding (48\%) }\end{array}$ \\
\hline
\end{tabular}

BS=cirurgia bariátrica; AUDIT=Alcohol Use Disorders Identification Test; WLS=cirurgia para perda de peso; RYGB=bypass gástrico Y-de-Roux; IMC=índice de massa corporal; LSG=gastrectomia vertical laparoscópica 
epidemiological methods, such as the longitudinal ones $7,8,10,15,16,17,23,29$ and one with population-based sample ${ }^{23}$.Still considering the methods, we highlight the existence of one qualitative study ${ }^{2}$.

Taking into account the surgical indications and in accordance to the objectives of this review, we have intended to list the high risk criteria that contraindicate the procedure, through the guidelines of American Society for Metabolic and Bariatric Surgery. Abusive history of psychoactive substances; regular use of alcohol pre-surgery; the realization of the Roux-in-Y gastric bypass (RYGB) and smoking ${ }^{21}$ are some of these criteria.

Among the high-risk criteria, checking the real prevalence of alcohol abuse during the postoperative period has been observed ${ }^{5,11,15,16,28}$. There is evidence that $3.0 \%{ }^{11}$ of individuals undergoing the surgery will develop problems resulting from the use of alcohol. At the same time, we observe an incidence of alcohol consumption of $4.9 \%^{8}$ and a $6 \%^{11}$ to $6.5 \%$ variation of prevalence in the postoperative period ${ }^{26}$.

Considering the pattern of alcohol consumption during the postoperative period, changes in this period are described $d^{5,11,18,26,28}$. There is a correlation between the use of alcohol with time after surgery, with an increase of $2 \%$ of alcohol consumption rate in two years in the postoperative ${ }^{15}$.

The postoperative time relationship was also described. Study found a lower prevalence of substance use in the period up to six months after surgery, while those who had a higher intake of alcohol were in over one year of the procedure. This can be justified by the discouraging alcohol consumption in the prior period to six months 5 .

With reference to the change in the pattern of alcohol use, its increase has been reported in 33\% of cross-sectional studies selected in this review $7,15,16,23,28$. On the other hand, in $13 \%$ of the studies, more precisely in the longitudinal studies ${ }^{10}$ the reduction of alcohol consumption after BS was estimated with a decrease of $9.1 \%{ }^{17}$.

Two studies addressed the reduction of alcohol use after weight reduction surgery referring to patients submitted to RYGB ${ }^{10,14}$. However, these are individuals or database studies, which contained only patients who were submitted exclusively to such surgical procedure. In this review, $40 \%$ of the studies investigated patients undergoing various techniques and showed different results, that is, we identified an increase in alcohol consumption in the postoperative with the RYGB procedure $7,8,15,23,27,28$

Other findings observed were related to hypoglycemic episodes, due to the reduced availability of glucose, by suppressing gluconeogenesis, a situation that gets worse with alcohol consumption ${ }^{5}$. Individuals are more sensitive to the effects of alcohol ${ }^{5,23,27}$ resulting in intoxication because of the quantity of alcohol ingested after $\mathrm{BS}^{11}$. We also noted an increasing prevalence of hospitalizations resulting from alcohol consumption, with men seeking more treatment compared to women ${ }^{11}$. In contrast, a higher prevalence of hospitalization in female and nonsmokers bariatric patients was also observed ${ }^{26}$.

Other remarks are about the possibility of transferring eating to alcohol consumption, which would strengthen the dependency status of this substance ${ }^{22,23}$. Patients with high body mass index are more likely to develop alcohol consumption during the postoperative period ${ }^{17}$. Also the weight loss appears as a risk factor for the consumption of alcohol during postoperative ${ }^{13}$.

The instruments used in the integrative review to verify the consumption of alcohol were Alcohol Use Disorders Identification Test (AUDIT) $)^{2,3,7,8,15,16,17,28,29}$ with a prevalence of $53.3 \%$; the SelfReport Questionnaire ${ }^{5,10,11,26}$ with $26.6 \%$; and the level of exhaled air with AlcoScan - AL-6000 (AlcoMateAlcotest) ${ }^{18}$ with $6.6 \%$, as well as records ${ }^{23}$, with $6.6 \%$ of prevalence. Interventional observational analysis was also performed, representing $6.6 \%$ of the studies ${ }^{27}$.

AUDIT $^{4}$, originally developed as a collaborative project of the World Health Organization in the late 1980s and validated in Brazil in 1999, is configured today as one of the measures employed worldwide for early detection screening of risk to the harmful use of alcohol. The same applies to the tracking of alcohol abuse in clinical samples and the general population ${ }^{12,25}$.

The AUDIT was used in different ways in these studies. Some applied this tracker before and after the surgical procedure ${ }^{15,17,29}$; others, at the time of data collection, generated risk estimation or dependence at the time of the survey ${ }^{7,8,28}$. Finally, the AUDIT was applied comparing bariatric patients with non-obese individuals suggesting the realization of a preventive AUDIT in patients who should undergo RYGB .

We emphasize the importance of pre-operative advice regarding the consumption of alcohol as a protective factor against the risk of alcohol abuse ${ }^{16}$. We should let the patients know about the adverse effects of alcohol, with the intention of reducing the consumption during the postoperative period. These studies also observed that the search for improvement in health figured as a motivation to reduce alcohol consumption ${ }^{7,16}$.

All studies analyzed generated variables for future research and raised the issue surrounding the weight loss process and health problems in particular with the use of alcohol.

\section{CONCLUSIONS}

In principle, we found differences in postoperative period and gender related to the use of alcohol. The prevalence and incidence of alcohol consumption had a variation of about six months to three years in postoperative period. As to gender, both sexes were involved, but there was a higher incidence of men seeking treatment because of alcoholic substance use.

However, there was no consensus about sensitivity to the use of alcohol, which increases after the BS. Smaller alcoholic doses cause greater toxicity, compared to the period prior to the surgery. Likewise, research studies have addressed more frequently studies on BS that used RYGB technique, because this is the most usual procedure for the surgical treatment of obesity, indicating the need for comparative studies with other common techniques.

Another relevant synthesis relates to the transfer of food cravings for alcohol consumption; however, it was found that this dimension has been discussed theoretically.

\section{REFERENCES}

1. Alexander E., A Selmyn, C. Calitz, D. Yach, Y.C. Wung Obesity: causes and prevalence Encyclopedia of Food and Health,2016, pags132-138.

2. Ashton K, Heinberg L, Merrell J, Lavery M, Windover A, Alcorn K. Pilot evaluation of a substance abuse prevention group intervention for at-risk bariatric surgery candidates. Surg Obes Relat Dis. 2013 MayJun;9(3):462-7. doi: 10.1016/j.soard.2013.01.016

3. Burgos MG, Cabral PC, Maio R, Oliveira BM, Dias MS, Melim DB, Correia MF. Prevalence of Alcohol Abuse Before and after Bariatric Surgery Associated With Nutritional and LifestyleFactors:AStudylnvolvingaPor tuguesePopulation. ObesSurg. 2015 setembro; 25 (9): 1716-1722. doi: 10,1007 / s11695-015-1609-7.

4. Babor TF, Higgins-Biddle J, Saunders J, Monteiro M. The alcohol use disorders identification test: guidelines for use in primary care. [internet] 2. ed. Genebra: World Health Organization; 2001. Disponíd em: http://whqlibdoc.who.int/hq/2001/who_msd_msb_01.6a.pdf. Acessadoem: 10 marc 2016.

5. Buffington CK. Alcohol use and health risks: survey results. Bariatric Times 2007:4(2);1,21-3.

6. Buffington CK A review of alcohol absorption and metabolism in nonsurgical and bariatric surgical patients. 2005.

7. Conason A, Teixeira J,Hsu CH,Puma L,Knafo D, Geliebter A.Substance use following bariatric weight loss surgery. JAMA Surg. 2013; 148(2): 145-50.

8. Cuellar-Barboza AB, Frye MA, Grothe K, Prieto ML, Schneekloth TD, Loukianova LL et al. Change in consumption patterns for treatmentseeking patients with alcohol use disorder post-bariatric surgery. J Psychosom Res. 2015; 78(3): 199-204.

9. Davis C, Carter JC. Compulsive overeating as an addiction disorder: a review of theory and evidence. Appetite. 2009; 53(1): 1-8. 
10. Davis JF,Schurdak JD,Magrisso IJ,Mul JD,Grayson BE,Pfluger PT et al. Gastric bypass surgery attenuates ethanol consumption in ethanolpreferring rats.Biol Psychiatry. 2012 Sep 1;72(5):354-60.

11. Ertelt TW,Mitchell JE,Lancaster K,Crosby RD,Steffen KJ,Marino JM. Alcohol abuse and dependence before and after bariatric surgery: a review of the literature and report of a new data set. SurgObesRelat Dis. 2008; 4(5): 647-50.

12. GAYA-Meneses C, Zuardi AW, Loureiro SR, Crippa JAS. Alcohol Use Disorders Identification Test (AUDIT): an updated systematic review ofpsychometricproperties. PsycholNeurosci. 2009;2(1):83-97.

13. Heinberg LJ, Ashton K. History of substance abuse relates to improved postbariatric body mass index outcomes. SurgObesRelat Dis. 2010; 6(4): 417-21.

14. Hagedorn JC, Encarnacion B, Brat GA, Morton JM. Does gastric bypass alter alcohol metabolism?SurgObesRelat Dis. 2007; 3(5):543-548 discussion548.

15. King WC,Chen JY,Mitchell JE,Kalarchian MA,Steffen KJ,Engel SG et al. Prevalence of alcohol use disorders before and after bariatric surgery. JAMA. 2012; 307(23): 2516-25.

16. Kudsi OY,Huskey K,Grove S,Blackburn G,Jones DB,Wee CC. Prevalence of preoperative alcohol abuse among patients seeking weight-loss surgery. SurgEndosc. 2013; 27(4): 1093-7.

17. Lent MR,Hayes SM,Wood GC,Napolitano MA,Argyropoulos G,Gerhard GS et al. Smoking and alcohol use in gastric bypass patients. Eat Behav.2013;14(4):460-3.

18. Maluenda F, Csendes A, De Aretxabala X, Poniachi k J,Salvo K,Delgadol et al. Alcohol absorption modification after a laparoscopic sleeve gastrectomy due to obesity. Obes Surg. 2010; 20(6): 744-8.

19. Melnyk BM, Fineout-Overholt E. Making the case for evidence-based practice. In: Melnyk BM, Fineout-Overholt E. Evidence based practice in nursing \& healthcare. A guide to best practice. Philadelphia: Lippincot Williams \&Wilkins; 2005. p. 3-24.

20. Mendes KD, Silveira RC, Galvão CM. Revisão integrativa: método de pesquisa para a incorporação de evidências na saúde e na enfermagem. Texto Contexto Enferm. 2008; 17(4):758-64. Portuguese. Texto Contexto Enferm [Internet]. 2008 [citado 2015 ago. 197/4//78 64. Disponível em:http://redenep.unisc.br/portal/upload/com_arquivo/ revisao integrativa metodo_de_pesquisa_para_incorporacao_de evidencias_na_saude_e_na_enfermagem.pdf
21. MechanickJI,KushnerRF,SugermanHJ,Gonzalez-CampoyJM,Collazo-Clavell ML, Guven S, Dixon J. American Association of Clinical Endocrinologists, TheObesitySociety, andAmericanSocietyforMetabolic\&BariatricSurgery Medical Guidelines for Clinical Practice for the perioperative nutritional, metabolic, and nonsurgical support of the bariatric surgery patient. SurgObesRelatDis.2008;4(5Suppl):S9-S12.doi:S1550-7289(08)00630-8

22. Moorehead M. Transfer of addiction and considerations for preventive measures in bariatric surgery. Bariatric Times. 2007.

23. OstlundMP,BackmanO,MarskR,StockeldD,LagergrenJ,RasmussenFetal. Increased admission foralcohol dependence aftergastric bypass surgery compared withrestrictivebariatricsurgery.JAMASurg.2013;148(4):374-7.

24. Prevedello CF, Colpo E. Análise do impacto da cirurgia bariátrica em uma população do Centro do Estado do Rio Grande do Sul utilizando o método BAROS. ArquGastroenterol. 2009; 46(3): 199-203.

25. Rist, F., Glockner-Rist, A., \&Demmel, R. (2009). The Alcohol Use Disorders Identification Test revisited: establishing its structure using nonlinear factor analysis and identifying subgroups of respondents using latent class factor analysis. Drug and Alcohol Dependence, 100(1-2), 71-82.

26. Saules KK, WiedemannA, IvezajV, HopperJA, Foster-HartsfieldJ, Schwarz D. Bariatric surgery history among substance abuse treatment patients: prevalenceandassociated features.SurgObesRelatDis.2010;6(6):615-21.

27. Sogg S. Alcohol misuse after bariatric surgery: epiphenomenon or "Oprah" phenomenon? SurgObesRel Dis. 2006; 3(3): 366-8.

28. Suzuki J, Haimovici F, Chang G. Alcohol use disorders after bariatric surgery. Obes Surg. 2012; 22(2): 201-7.

29. WeeCC,HamelMB,ApovianCM,BlackburnGL,Bolcic-JankovicD,ColtenMEet al. Expectationsforweightlossand willingnesstoacceptriskamongpatients seeking weight loss surgery. JAMA Surg. 2013; 148(3): 264-71.

30. Wee C.C.,MukamalKJ,HuskeyKW, DavisRB,ColtenME,Bolcic-JankovicD et al. High-risk alcohol use after weight loss surgery. SurgObesRelat Dis. 2014; 10(3): 508-13. 